\title{
Assessment of Views Opinions and Perceptions of Pharmacy Students towards Doctor of Pharmacy Profession in India
}

\author{
Sai Krishna Gudi* \\ Department of Pharmacy, Rady Faculty of Health Sciences, University of Manitoba, Winnipeg, MB, CANADA.
}

\begin{abstract}
Background: Although clinical pharmacy is considered as one of the most vibrant and exigent professions, when it comes to the recognition, scope and the career opportunities for Pharm D professionals are ill-defined in the current scenario of Indian Pharmacy. The SPICE-PHARM study (Suggestions, Perceptions and Ideas for Comprehensive Education system towards Pharmacy profession) primarily aims at the various views, opinions and perceptions of Pharm D students in order to enhance the standards with respect to the recognition and address future career opportunities in particular to Indian context. Materials and Methods: A cross-sectional survey was conducted by using a semistructured, pre-tested self-administered questionnaire which was validated through a pilot study conducted with 20 respondents prior to the full-fledged study. Survey was conducted at various educational institutions of India primarily using google document forms over a period of six months. The responses were collected and analyzed by using descriptive statistics. Results: By analysing the survey results, majority of the participants has showed desire for the specific issues that needs to be addressed. Also, results clearly represents that there is an absolute need for enhancing the standards with regards to the respect, identity and cadre towards the Pharm D profession in India. Conclusion: Our survey emphasized on the views, opinions and perceptions with regards to Pharm D profession in India. In a nutshell, survey result concludes that there is an immense need for development in the educational and professional standards of Doctor of Pharmacy in India.
\end{abstract}

Key words: Doctor of Pharmacy, Pharm D Profession in India, Pharmacy students, Clinical Pharmacy, Cross sectional study, Questionnaire-based survey.

\section{INTRODUCTION}

In the past, pharmacists were solely restricted to manufacturing and dispensing of medications. ${ }^{1}$ Chronologically, the traditional role of pharmacist is expanding and now pharmacists are considered as the integral part of healthcare team, especially the new generation clinical pharmacists with respect to patient centric care. ${ }^{2-3}$ Pharmaceutical education plays a very prominent role in attaining sustainable and equitable development of a country. ${ }^{3}$ Pharmacists comprise the third largest healthcare professionals in the world and pharmacy profession has been evolving steadily over the last decade in India. The scope and potential for growth of Pharm $\mathrm{D}$ profession is enormous, if the standards upgrade to international and global expectations. ${ }^{4}$ Clinical Pharmacists in developing countries like India are still underutilized and their role as health care professionals is not deemed important by either the community or other health care providers, though they are considered as the drug therapy experts with potentiality of optimizing medication use which aids patients with positive health outcomes. ${ }^{4-5}$ The SPICEPHARM study mainly emphasize on the interim status of the Doctor of Pharmacy
Submission Date: 09-03-2018; Revision Date: 05-06-2018; Accepted Date: 14-08-2018

DOI: 10.5530/ijper.53.1.6 Correspondence: Dr. Sai Krishna Gudi, B. Pharm, Pharm. D, (MSc), 750 McDermot Ave W, Winnipeg, MB R3E 0T5, CANADA.

Phone: + 1 431-336(8099) E-mail: sknanu06@gmail. com

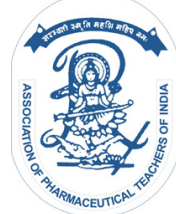

www.ijper.org 
profession in India. The information presented in this paper might stimulate discussion on critical analysis and planning, thus it would be of value in future adaptation of the Pharm D profession for desired beneficial outcomes as a result.

\section{OBJECTIVE}

To assess the views, opinions and perceptions of Pharm D students towards Doctor of Pharmacy profession in India.

\section{MATERIALS AND METHODS}

\section{Study Procedure}

A cross-sectional survey was conducted by using semistructured, pre-tested self-administered questionnaire over a period of six months i.e. from August 2017 to January 2018 among the Pharm D students at various colleges and universities around India by using google document forms which was easy, quick and reliable to collect wide range of responses around the country. The survey cohort was restricted to the students of final year ( $5^{\text {th }}$ year), Interns and recently graduated Pharm D professionals as they might have broader knowledge, considerable opinions and accountable views towards Doctor of Pharmacy profession in India.

\section{Designing of Survey Questionnaire}

A survey questionnaire was designed based on the study objective and respondents in mind. The questionnaire was framed with closed ended questions with multiple choices as responses to be selected in order to collect the required information. As the designing of questionnaire is a challenging process, the survey questions' structure, sequence and pattern were revised and peer reviewed. Then questionnaire was evaluated for validity by using face and content validation methods and then assessed for reliability by using test-retest and splithalf methods through a pilot study conducted with 20 respondents prior to the full-fledged survey. The questionnaire consists a total of 22 questions, out of which 8 questions each are related to views and opinion domain, whereas 6 questions are related to perceptions domain respectively.

\section{Statistical Analysis}

The study participants were segregated based on their age, gender and year of the study. The responses were collected and entered into Microsoft excel spread sheet for sorting and analyzed by using SPSS version 14 for descriptive statistics of study participant characteristics.

\section{RESULTS AND DISCUSSION}

A total of 369 participant responses were collected from various Pharmacy colleges across India. The mean age of the participants was found to be 25.09 with a standard deviation of 1.8. However, nearly one-fourth $(23 \%)$ of the study participants were 23 years of age. Among the study cohort, 152 were males $(41.2 \%)$ and 217 were females $(58.8 \%)$. These findings are in accordance with the similar study performed by Flora Keshishian et al. which consists of $47 \%$ of male and $53 \%$ of female pharmacy students. ${ }^{6}$ The number of responses provided by final year Pharm D students, interns and graduates were found to be 138 (37.4\%), $99(26.8 \%)$ and $132(35.8 \%)$ respectively as represented in Table 1.

\section{Views towards Doctor of Pharmacy Profession in India}

Among the responses of questions related to views among Pharm D students towards their profession, more than three-fourth of study participants 302 $(81.8 \%)$ agreed that there is a need for mandatory competency entrance examination for Pharm D. The reason for such a response from the participants might be because, they felt the profession lacks the quality due to significant number of institutions getting permissions for Pharm D which might indirectly trigger enrolling vast number of students with inadequate knowledge. ${ }^{2}$ Interestingly, more than two-third $(78 \%)$ of them positively responded towards need for collaboration with foreign country universities for better standards and opportunities and around $85 \%$ of the students showed a positive inclination towards Pharm D students and academic staff attending international conferences

\begin{tabular}{|c|c|c|c|}
\hline Item & Category & $\begin{array}{c}\text { Study } \\
\text { participants } \\
\text { Total }(n)=369\end{array}$ & $\begin{array}{c}\text { Percentages } \\
(\%)\end{array}$ \\
\hline \multirow{7}{*}{$\begin{array}{c}\text { Age } \\
\text { Mean } \pm \\
\text { S.D } \\
(25.09 \pm \\
1.8)\end{array}$} & 23 & 85 & $23 \%$ \\
\hline & 24 & 66 & $17.9 \%$ \\
\hline & 25 & 70 & $19 \%$ \\
\hline & 26 & 56 & $15.1 \%$ \\
\hline & 27 & 42 & $11.4 \%$ \\
\hline & 28 & 30 & $8.1 \%$ \\
\hline & 29 & 20 & $5.4 \%$ \\
\hline \multirow[b]{2}{*}{ Gender } & Male & 152 & $41.2 \%$ \\
\hline & Female & 217 & $58.8 \%$ \\
\hline \multirow{3}{*}{$\begin{array}{l}\text { Year of } \\
\text { study }\end{array}$} & Final year & 138 & $37.4 \%$ \\
\hline & Intern & 99 & $26.8 \%$ \\
\hline & Graduate & 132 & $35.8 \%$ \\
\hline
\end{tabular}


abroad to broaden their vision. The rationale behind such responses might be that, unlike in India most of the developed countries have Pharm D since decades which would have made them eminent epitomes with regards to the scope, standards and career opportunities for many developing countries like India. ${ }^{7}$ Around two-third $(65 \%)$ of the students positively responded towards need for student exchange programs with foreign universities in order to have better scientific exposure and fruitful learning. So, participants might have thought attending conferences, visiting abroad universities as a student for exchange between the universities and getting collaborated with such paramount universities around the world would aid them in bridging the gap between their dreams and reality. Nearly $80 \%$ of the students agreed that there is need to organize frequent seminars and workshops at institution level for better understanding of career opportunities. As all of us are aware of the fact that Pharm D is the new born course in India most of the students, graduates and professionals might lack the knowledge with regards to the scope and future opportunities about the profession. ${ }^{3}$ Surprisingly, $266(72.1 \%)$ students want institutions to invest the academic funds in research related activities which can assist in creating young research scholars. Astonishingly, 336 (91\%) students claimed towards need for licensing examination for registration as a pharmacist in India like in other countries. As known to all, India doesn't have a specific competency examination for registering as a licensed Pharmacist, which could lead to shallow archetype trait in near future in context of Indian Pharmacy. Most of the study responses are in accordance with the similar study conducted by Garipelly. $\mathrm{R}$ et al. ${ }^{7}$ Detailed responses regarding the views of study participants are listed in Table 2.

\section{Opinions towards Doctor of Pharmacy Profession in India}

Among the responses of questions related to opinions among Pharm D students towards their profession, half of the participants $185(50.1 \%)$ mentioned that they joined the course because they get "Dr." as a prefix, however $128(34.7 \%)$ students replied "may be" for the same. As we all aware of a fact that Pharm D is a doctoral program, ${ }^{3}$ it could serve as an asset from a student's point of view to secure a respectful position in the society. Interestingly, more than half of the participants 191 (51.8\%) mentioned that they will not suggest Pharm D as a career to others. This response might be because of dilemma within students regarding the scope and further career options. Nearly $82 \%$ of the study participants agreed that there is a need for Pharm

\begin{tabular}{|c|c|c|c|}
\hline Questions & Yes & No & May be \\
\hline $\begin{array}{c}\text { Do you think there is } \\
\text { a need for mandatory } \\
\text { competency entrance } \\
\text { examination for Pharm } \\
\text { D in India? }\end{array}$ & $\begin{array}{c}302 \\
(81.8 \%)\end{array}$ & $\begin{array}{c}22 \\
(6 \%)\end{array}$ & $\begin{array}{c}48 \\
(13 \%)\end{array}$ \\
\hline $\begin{array}{l}\text { Do you think there is a } \\
\text { need for collaboration } \\
\text { between India and other } \\
\text { foreign universities for } \\
\text { raising standards at } \\
\text { institutional level? }\end{array}$ & $\begin{array}{c}288 \\
(78 \%)\end{array}$ & $\begin{array}{c}19 \\
(5.1 \%)\end{array}$ & $\begin{array}{c}62 \\
(16.8 \%)\end{array}$ \\
\hline $\begin{array}{l}\text { Do you think Pharm } \\
\text { D graduates and } \\
\text { academic staff should } \\
\text { attend international } \\
\text { seminars and } \\
\text { conferences abroad } \\
\text { for better development } \\
\text { in the educational } \\
\text { standards? }\end{array}$ & $\begin{array}{c}312 \\
(84.5 \%)\end{array}$ & $\begin{array}{c}23 \\
(6.2 \%)\end{array}$ & $\begin{array}{c}34 \\
(9.2 \%)\end{array}$ \\
\hline $\begin{array}{l}\text { Do you think there is } \\
\text { a need to organize } \\
\text { frequent seminars } \\
\text { and workshops by } \\
\text { collaboration with the } \\
\text { industry for better } \\
\text { understanding with } \\
\text { regards to career } \\
\text { opportunities? }\end{array}$ & $\begin{array}{c}294 \\
(79.7 \%)\end{array}$ & $\begin{array}{c}46 \\
(12.5 \%)\end{array}$ & $\begin{array}{c}29 \\
(7.8 \%)\end{array}$ \\
\hline $\begin{array}{l}\text { Do you think investing } \\
\text { academic funds in } \\
\text { research related } \\
\text { activities will assist in } \\
\text { creating young research } \\
\text { scholars? }\end{array}$ & $\begin{array}{c}266 \\
(72.1 \%)\end{array}$ & $\begin{array}{c}50 \\
(13.5 \%)\end{array}$ & $\begin{array}{c}53 \\
(14.4 \%)\end{array}$ \\
\hline $\begin{array}{l}\text { Do you think there } \\
\text { is a need to update } \\
\text { the knowledge of } \\
\text { teaching staff through } \\
\text { continuing medical } \\
\text { education (CME's) } \\
\text { in order to maintain } \\
\text { their competency and } \\
\text { innovativeness? }\end{array}$ & $\begin{array}{c}216 \\
(58.5 \%)\end{array}$ & $\begin{array}{c}62 \\
(16.8 \%)\end{array}$ & $\begin{array}{c}91 \\
(24.7 \%)\end{array}$ \\
\hline $\begin{array}{l}\text { Do you think there } \\
\text { is a need for student } \\
\text { exchange programs } \\
\text { with foreign universities } \\
\text { in order to have better } \\
\text { scientific exposure and } \\
\text { fruitful learning? }\end{array}$ & $\begin{array}{c}239 \\
(64.8 \%)\end{array}$ & $\begin{array}{c}46 \\
(12.4 \%)\end{array}$ & $\begin{array}{c}84 \\
(22.8 \%)\end{array}$ \\
\hline $\begin{array}{c}\text { Do you think there is } \\
\text { a need for licensing } \\
\text { examination for } \\
\text { registration as a } \\
\text { pharmacist in India like } \\
\text { in other countries such } \\
\text { as NAPLEX, PEBC, } \\
\text { APEC, MOH and DHA } \\
\text { etc.? }\end{array}$ & $\begin{array}{c}336 \\
(91 \%)\end{array}$ & $\begin{array}{c}8 \\
(2.2 \%)\end{array}$ & $\begin{array}{c}25 \\
(6.8 \%)\end{array}$ \\
\hline
\end{tabular}


D course in India. A recent study conducted by Vikas Bajpai et al. quoted that India has one government doctor for every 11,528 people and one nurse for every 483 people. ${ }^{8}$ This clearly depicts the current scenario of doctor-patient relationship. As most of the doctors might not have enough time to discuss the disease and drug related problems with the patients, there comes the role of clinical pharmacist. ${ }^{9-10}$ Surprisingly, 225 (61\%) students claimed that the profession is not valued in the way it deserves. Nearly $64 \%$ of the participants mentioned that Indian Pharm D doesn't have the scope like other developed countries do. As Pharm D is young and emerging course in India, definitely it takes some time to take existence and gain what actually aimed for. Around $62 \%$ of the participants agreed that Pharm $\mathrm{D}$ graduates should participate in the ongoing health camps and campaigns. In a paper authored by Sachan $\mathrm{D}$ et al. and Jain A et al. they clearly mentioned various pitfalls in the current medical profession and there is a need for all healthcare professionals in order to strive for better patient care. ${ }^{11-12}$ Out of 369 participants, 316 $(85.6 \%)$ students agreed that Pharm D professionals can able to minimize medication errors, maximize costeffectiveness and improve patient outcomes. In a study conducted by Foroughinia $\mathrm{F}$ et al. and Khalili $\mathrm{H}$ et al. stated that clinical pharmacist can efficiently detect and manage drug related problems in health care settings. ${ }^{13-14}$ And 304 (82.4\%) students suggested that there should be an enhanced inter-professional relationship between Clinical Pharmacist and a physician for better patient care. A study conducted by Mishra A et al. strongly suggests that collaboration between clinical pharmacist and a physician would predominantly yields significant patient outcomes. ${ }^{15-16}$ Detailed responses regarding the opinions of study participants are listed in Table 3.

\section{Perceptions towards Doctor of Pharmacy Profession in India}

Among the responses of questions related to perceptions among Pharm D students towards their profession, around three-fourth $(72.1 \%)$ of the participants claimed that pharmacists are not just meant for dispensing of the prescribed drugs. Nearly $75 \%$ of the students mentioned that there is a need for clinical pharmacist in the hospital care settings. In a study conducted by Viktil KK et al. and Blix HS et al. concluded that clinical pharmacist has a vibrant role in the disease management in the hospital care settings, ${ }^{17,18}$ and more than three-fourth of the participants 283 (76.7\%) agreed that clinical pharmacist is an integral part of the health care team. In a study conducted by Deshpande P.R et al. stated that clinical pharmacists are the major

\begin{tabular}{|c|c|c|c|}
\hline Questions & Yes & No & May be \\
\hline $\begin{array}{l}\text { I joined Pharm D because I } \\
\text { get "Dr." as a prefix. }\end{array}$ & $\begin{array}{c}185 \\
(50.1 \%)\end{array}$ & $\begin{array}{c}56 \\
(15.2 \%)\end{array}$ & $\begin{array}{c}128 \\
(34.7 \%)\end{array}$ \\
\hline $\begin{array}{l}\text { Do you suggest Pharm D } \\
\text { as a career to others? }\end{array}$ & $\begin{array}{c}129 \\
(34.9 \%)\end{array}$ & $\begin{array}{c}191 \\
(51.8 \%)\end{array}$ & $\begin{array}{c}49 \\
(13.3 \%)\end{array}$ \\
\hline $\begin{array}{l}\text { Do you think there is a } \\
\text { need for Pharm D course } \\
\text { in India? }\end{array}$ & $\begin{array}{c}307 \\
(83.2 \%)\end{array}$ & $\begin{array}{c}25 \\
(6.8 \%)\end{array}$ & $\begin{array}{c}37 \\
(10 \%)\end{array}$ \\
\hline $\begin{array}{l}\text { Do you think the Pharm } \\
\text { D profession is valued in } \\
\text { the way it deserves in the } \\
\text { current scenario? }\end{array}$ & $\begin{array}{c}96 \\
(26 \%)\end{array}$ & $\begin{array}{c}225 \\
(61 \%)\end{array}$ & $\begin{array}{c}48 \\
(13 \%)\end{array}$ \\
\hline $\begin{array}{l}\text { Do you think Indian Pharm } \\
\text { D has equal scope as like } \\
\text { other countries such as } \\
\text { USA, Canada and Australia } \\
\text { etc.? }\end{array}$ & $\begin{array}{c}84 \\
(22.8 \%)\end{array}$ & $\begin{array}{c}236 \\
(63.9 \%)\end{array}$ & $\begin{array}{c}49 \\
(13.3 \%)\end{array}$ \\
\hline $\begin{array}{c}\text { Do you think Pharm } \\
\text { D graduates should } \\
\text { participate in the ongoing } \\
\text { health camps and } \\
\text { campaigns such as polio } \\
\text { eradication, family planning } \\
\text { and disease awareness } \\
\text { etc.? }\end{array}$ & $\begin{array}{c}228 \\
(61.8 \%)\end{array}$ & $\begin{array}{c}46 \\
(12.5 \%)\end{array}$ & $\begin{array}{c}95 \\
(25.7 \%)\end{array}$ \\
\hline $\begin{array}{l}\text { Do you think Pharm D } \\
\text { professionals can able } \\
\text { to minimize medication } \\
\text { errors, maximize cost- } \\
\text { effectiveness and improve } \\
\text { patient outcomes? }\end{array}$ & $\begin{array}{c}316 \\
(85.6 \%)\end{array}$ & $\begin{array}{c}10 \\
(2.7 \%)\end{array}$ & $\begin{array}{c}43 \\
(11.6 \%)\end{array}$ \\
\hline $\begin{array}{l}\text { Do you think there should } \\
\text { be an enhanced inter- } \\
\text { professional relationship } \\
\text { between Clinical } \\
\text { Pharmacist and a physician } \\
\text { for better patient care? }\end{array}$ & $\begin{array}{c}304 \\
(82.4 \%)\end{array}$ & $\begin{array}{c}9 \\
(2.4 \%)\end{array}$ & $\begin{array}{c}56 \\
(15.2 \%)\end{array}$ \\
\hline
\end{tabular}

support to Indian healthcare system. ${ }^{19}$ Around $85 \%$ of the students claimed that Pharm D should be implemented as a qualification for registration as a pharmacist in India. Approximately, $90 \%$ of the participants agreed that clinical pharmacist should be appointed at the PHC (Public Health Centre) and CHC (Community Health Centre) at villages and rural areas. ${ }^{9}$ Astonishingly, only one-fourth $98(26.5 \%)$ of the participants agreed that doctors and other healthcare staff will accept the interventions made by clinical pharmacists. In a study conducted by ND Barber et al. declared that most of the physicians would accept the clinical interventions made by the clinical pharmacists in healthcare settings, which are in contrast with the current survey results. ${ }^{20}$ Detailed responses regarding the perceptions of study participants are listed in Table 4.

Over all these explorations, technical and controlling authorities of this country should strictly control, monitor, 


\begin{tabular}{|c|c|c|c|}
\hline Questions & Yes & No & May be \\
\hline $\begin{array}{l}\text { Pharmacists are only meant } \\
\text { for dispensing of prescribed } \\
\text { drugs? }\end{array}$ & $\begin{array}{c}42 \\
(11.4 \%)\end{array}$ & $\begin{array}{c}266 \\
(72.1 \%)\end{array}$ & $\begin{array}{c}61 \\
(16.5 \%)\end{array}$ \\
\hline $\begin{array}{l}\text { There is a need for Clinical } \\
\text { Pharmacists in the hospital } \\
\text { care settings. }\end{array}$ & $\begin{array}{c}271 \\
(73.4 \%)\end{array}$ & $\begin{array}{c}29 \\
(7.8 \%)\end{array}$ & $\begin{array}{c}69 \\
(18.7 \%)\end{array}$ \\
\hline $\begin{array}{l}\text { Clinical pharmacist is an } \\
\text { important and integral part } \\
\text { of the health care team. }\end{array}$ & $\begin{array}{c}283 \\
(76.7 \%)\end{array}$ & $\begin{array}{c}40 \\
(10.8 \%)\end{array}$ & $\begin{array}{c}46 \\
(12.5 \%)\end{array}$ \\
\hline $\begin{array}{l}\text { Pharm D should be } \\
\text { implemented as a } \\
\text { qualification for registration } \\
\text { as a pharmacist in India? }\end{array}$ & $\begin{array}{c}311 \\
(84.3 \%)\end{array}$ & $\begin{array}{c}19 \\
(5.1 \%)\end{array}$ & $\begin{array}{c}39 \\
(10.6 \%)\end{array}$ \\
\hline $\begin{array}{c}\text { Clinical Pharmacists should } \\
\text { be appointed at the PHC } \\
\text { (Public Health Centre) and } \\
\text { CHC (Community Health } \\
\text { Centre) at villages and rural } \\
\text { areas. }\end{array}$ & $\begin{array}{c}329 \\
(89.1 \%)\end{array}$ & $\begin{array}{c}19 \\
(5.1 \%)\end{array}$ & $\begin{array}{c}21 \\
(5.7 \%)\end{array}$ \\
\hline $\begin{array}{l}\text { Doctors and other } \\
\text { healthcare staff will accept } \\
\text { the interventions made } \\
\text { by clinical pharmacists } \\
\text { in patient disease } \\
\text { management. }\end{array}$ & $\begin{array}{c}98 \\
(26.5 \%)\end{array}$ & $\begin{array}{c}99 \\
(26.8 \%)\end{array}$ & $\begin{array}{c}172 \\
(46.6 \%)\end{array}$ \\
\hline
\end{tabular}

assess, and evaluate the quality while accrediting pharmacy institutions with respect to syllabus, academic staff and student quality and feedback. Also study results evidently proven that, present situation intimates low quality output as per demand, which would indirectly affect overall development of the society and country as well. The students should also be made to understand their responsibilities and importance of their service so that they strive hard to produce better care for the patients. $^{2}$

\section{CONCLUSION}

To compete with the thriving advancements in the field of pharmacy across the globe there is a compelling need to initiate an academic exercise aimed at attaining revamping of standards, keeping in pace with current and emerging trends. Survey results predominantly concludes that there is an urge for improvement with respect to the educational and professional standards towards Doctor of Pharmacy course in India. If the country's pharmacy authorities be able to consider and adopt the view, opinions and suggestions provided by the Pharm D students, it can lead to a tremendous and sustained raise in the quality growth of Indian pharmacy education and profession as well.

\section{ACKNOWLEDGEMENT}

Author explicit sincere gratitude to all the Pharm D students and graduates from various colleges and universities around India for allotting their time and support in order to fill the survey questionnaire.

\section{CONFLICT OF INTEREST}

There are no conflicts of interest.

\section{ABBREVIATIONS}

Pharm D: Doctor of Pharmacy; SPICE-PHARM study: Suggestions, Perceptions and Ideas for Comprehensive Education system towards Pharmacy profession; SPSS: Statistical Package for the Social Sciences; S.D: Standard Deviation; CME: Continuing Medical Education; NAPLEX: The North American Pharmacist Licensure Examination; PEBC: The Pharmacy Examining Board of Canada; APEC: The Australian Pharmacy Examining Committee; MOH: Ministry of Health; DHA: Dubai Health Authority.

\section{REFERENCES}

1. Cooper $\mathrm{Cl}$. Present and future prospects of Pharmaceutical education. Journal of the National Medical Association. 1940;32(1):6-10.

2. Deshpande PR, Farooq KK, John DM, Rao EJ. Pharm D: A new concept in India. J Pharm Bioallied Sci. 2012;4(1):84-6.

3. Krishna SG. Doctor of Pharmacy: A New Born and Emerging Course in India. Res Pharm Health Sci. 2015;1(1):35-41.

4. Mateti UV, Anantha NN. Doctor of pharmacy in India: Scope and professional challenges. J Pharm Res. 2011;10(3):97-101.

5. Basak SC, Satyanarayana D. Pharmacy practice in India: past, present, and future. Southern Med Review. 2009;2(1):11-4.

6. Keshishian F, Brenton B. Pharmacy Students' Perceptions of Their Curriculum and Profession: Implications for Pharmacy Education. Pharmacy Education. 2011;11(1):194-200.

7. Garipelly R, Garg S, Mateti UV. Emerging doctor of pharmacy program in India: A survey on general opinion of selected educated Indians. Journal of Research in Pharmacy Practice. 2012;1(2):48-54.

8. Vikas Bajpai. The Challenges Confronting Public Hospitals in India, Their Origins, and Possible Solutions. Advances in Public Health. 2014;1(1):1-28.

9. Sharma, Dinesh C. India still struggles with rural doctor shortages. The Lancet. 2015;386(1011):2381-2.

10. Kane S, Calnan M. Erosion of trust in the medical profession in India: time for doctors to act. Int J Health Policy Manag. 2017;6(1):5-8.

11. Sachan D. Tackling corruption in Indian medicine. Lancet. 2013;382(9905):23-4.

12. Jain A, Nundy S, Abbasi K. Corruption: medicine's dirty open secret. BMJ. 2014;348(4184):1-2.

13. Foroughinia F, Tazarehie SR, Petramfar P. Detecting and managing drugrelated problems in the neurology ward of a tertiary care teaching hospital in Iran: A clinical pharmacist's intervention. Journal of Research in Pharmacy Practice. 2016;5(4):285-9.

14. Khalili H, Farsaei S, Rezaee H, Dashti-Khavidaki S. Role of clinical pharmacists' interventions in detection and prevention of medication errors in a medical ward. Int J Clin Pharm. 2011;33(1):281-4.

15. Mishra A, Krishna GS, Alla S, Kurian TD, Kurian J, Ramesh M, et al. Impact of Pharmacist-Psychiatrist Collaborative Patient Education on Medication Adherence and Quality of Life (QOL) of Bipolar Affective Disorder (BPAD) Patients. Front Pharmacol. 2017;8(722):1-5. 
Mishra A, Krishna GS, Sravani A, Kurian TD, Kurian J, Ramesh M, et al. Impact of pharmacist-led collaborative patient education on medication adherence and quality of life of schizophrenia patients in a tertiary care setting. Bulletin of Faculty of Pharmacy Cairo University. 2017;55(2):345-9

17. Viktil KK, Blix HS. The Impact of Clinical Pharmacists on Drug-Related Problems and Clinical Outcomes. Basic Clin Pharmacol Toxicol. 2008;102(3):275-80

PICTORIAL ABSTRACT

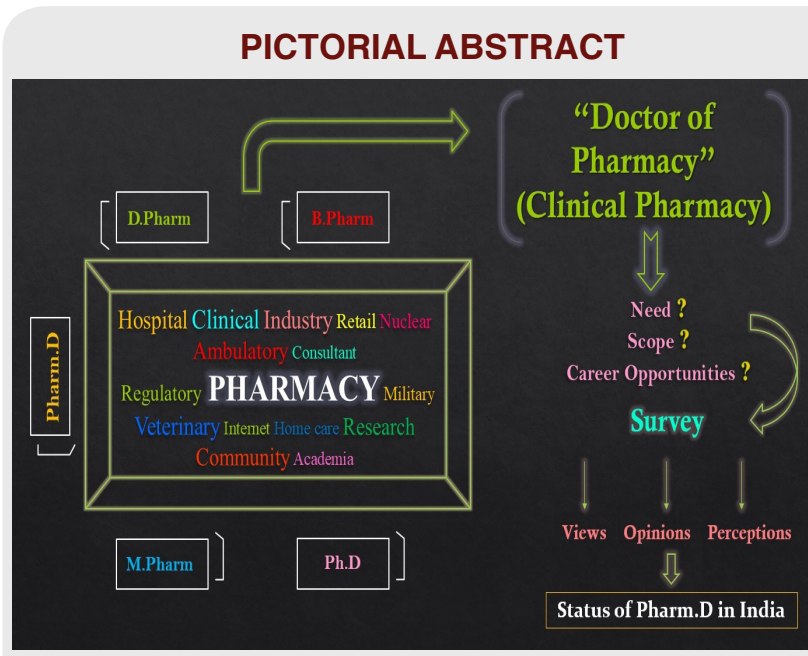

18. Blix HS, Viktil KK, Moger TA, Reikvam A. Characteristics of drug-related problems discussed by hospital pharmacists in multidisciplinary teams. Pharm World Sci. 2006;28(3):152-8.

19. Deshpande PR, Vantipalli R, Chaitanya LCH, Rao EJ, Regmi B, Ahad A, et al. Clinical pharmacists: The major support to Indian healthcare system in near future. Journal of Pharmacy and Bioallied Sciences. 2015;7(3):161-74.

20. Barber ND, Batty R, Ridout DA. Predicting the rate of physician-accepted interventions by hospital pharmacists in the United Kingdom. Am J Health Syst Pharm. 1997;54(1):397-405.

\section{SUMMARY}

- Alongside the various branches in the field of pharmacy, clinical pharmacy plays an integral part of healthcare team with respect to patient centric care.

- At present in India the recognition, scope and the career opportunities for Pharm D professionals are ill-defined.

- This SPICE-PHARM study aims at the various views, opinions and perceptions of Pharm D students in order to enhance the standards with respect to the recognition and address future career opportunities in particular to Indian context.

- This survey is considered as the first of its kind, conducted in order to assess the views, opinions and perceptions of Pharm D students as well as recent graduates towards Doctor of Pharmacy educations and profession in India.

- Survey results depicted that there is a need for expeditious advancements in norms in order to raise the standards of the course and make it well established in India.

- Through this survey we wish to stimulate discussion on critical analysis and planning, which would be of a value in future adaptation of the Pharm D profession for desired beneficial outcomes as a result.

\section{About Authors}

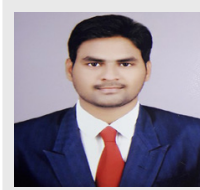

Dr. Sai Krishna Gudi is a research graduate pursuing his MSc (2017-19) at the Department of Pharmacy, University of Manitoba, Canada. He has done his bachelors in Pharmacy (2010-14) from SIMS college of Pharmacy, A.N.U University, Guntur, Andhra Pradesh, India. Also, he has done his Masters in Doctor of Pharmacy (2014-17) from JSS University, Mysore, Karnataka, India as a postbaccalaureate. Of now, he has authored around 30 papers which were published in both national and international journals as well. So far, he has attended about 10 Seminars and Conferences, more than 30 Poster and Oral Presentations, around 15 Workshops and $10 \mathrm{CME}^{\prime} \mathrm{s}$ and also various correspondence Diplomas and online Certifications in the field of Pharmacy from reputed organizations around the world. He is also a member of numerous National and International Societies. Throughout his journey in the profession of Pharmacy, he has received various Scholarships and Awards. His research interest includes Knowledge Translation through Evidence-Based Practice, Optimizing Irrational Drug-use, Pharmacoepidemiology, Pharmacy Education, Pharmacist Interventions, Patientoriented Outcomes, and various aspects of Pharmacy Practice. Currently, his research aims at the intensity of potential over-treatment related to glycemic targets among the elderly population with Diabetes across Canada.

Cite this article: Gudi SK. Assessment of Views, Opinions and Perceptions of Pharmacy Students towards Doctor of Pharmacy Profession in India. Indian J of Pharmaceutical Education and Research. 2019;53(1):42-7. 